https://doi.org/10.15407/ukrbotj77.06.428

\title{
The flora of the Batumi landfill (Adjara, Georgia)
}

\author{
Irakli Sh. MIKELADZE ${ }^{1}$, Aleksandre Sh. SHARABIDZE ${ }^{2}$ \\ ${ }^{1}$ Institute of Phytopathology and Biodiversity, Shota Rustaveli State University of Batumi \\ 6200 Kobuleti, Georgia \\ irakli.mikeladze@bsu.edu.ge \\ ${ }^{2}$ Department of Biology, Shota Rustaveli State University of Batumi \\ 6010 Batumi, Georgia \\ sharabidze.a@gmail.com
}

Mikeladze I.Sh., Sharabidze A.Sh. 2020. The flora of the Batumi landfill (Adjara, Georgia). Ukrainian Botanical Journal, 77(6): 428-433.

Abstract. Results of floristic research conducted within the territory of the Batumi landfill (Adjara, Georgia) are presented. The total area of the site is about 20 hectares, of which 10 hectares are active and the remaining part was closed in the beginning of the $21^{\text {st }}$ century. In the closed area, the processes of formation of stabilized plant communities and spontaneous vegetation successions are going on. As a result of the survey, we revealed 244 species of vascular plants belonging to 163 genera of 59 families. Among them, 86 species are considered native and 158 species are alien. Among the listed species, 94 are representatives of the ruderal flora and others are species characteristic for various other habitats.

Keywords: Adjara, alien flora, Batumi, landfill, life forms, ruderal species

Supplementary Material. Electronic Supplement (Table E1, e1-e7) is available in the online version of this article at: https://ukrbotj.co.ua/archive/77/6/428

Submitted 03 September 2019. Published 24 December 2020

Мікеладзе І.Ш. ${ }^{1}$, Шарабадзе А.Ш. ${ }^{2}$ 2020. Флора сміттєзвалища міста Батумі (Аджарія, Грузія). Український ботанічний журнал, 77(6): 428-433.

${ }^{1}$ Інститут фітопатології та біорізноманіття, Батумський державний університет імені Шота Руставелі

6200 Кобулеті, Грузія

${ }^{2}$ Кафедра біології, Батумський державний університет імені Шота Руставелі

6010 Батумі, Грузія

Реферат. Представлено результати флористичних досліджень, проведених на території сміттєзвалища м. Батумі (Аджарія, Грузія). Загальна площа ділянки становить близько 20 га, з них 10 га займає діючий об'єкт, решта території була закрита на початку XXI століття. У закритій зоні триває формування стійких рослинних угруповань, а також відбуваються стихійні сукцесійні процеси в рослинному покриві. Внаслідок проведених спостережень ми виявили 244 види судинних рослин, що належать до 163 родів із 59 родин. Серед них 86 видів вважаються аборигенними, а 158 видів - чужорідними. 3 наведених видів $94 \epsilon$ представниками рудеральної флори, решта - види, характерні для інших типів оселищ.

Ключові слова: Аджарія, Батумі, звалище, життєві форми, рудеральні види, чужорідна флора

\section{Introduction}

There are no present-day local floras in the world that have not been exposed to at least some, direct or indirect, anthropogenic impact. The anthropogenic transformation of vegetation covers all territories where human activities are manifested even to a minimal extent. As a result of the global anthropogenic impact, technogenic ecotopes are formed; those ecotopes have no natural analogues and they are often results of urbanization and include urban landscapes inhabited by species of the urban flora, ruderal flora, etc.
The urbanization index in Georgia is currently 53\%. Among the cities and towns of Georgia, the city of Batumi is characterized by the fast urban growth and development.

In the middle of the $20^{\text {th }}$ century the population of Batumi, according to the official data, was only slightly more than 82 thousand inhabitants. However, at the beginning of the $21^{\text {st }}$ century it reached 120 thousand, and by 2018 the current estimate is ca. 163 thousand people or, according to unofficial data, even more. With the increase of its population, the city area was growing as well.

(C) 2020 I.Sh. Mikeladze, A.Sh. Sharabidze. Published by the M.G. Kholodny Institute of Botany, NAS of Ukraine. This is an open access article under the terms of the Creative Commons Attribution License (http://creativecommons.org/licenses/by/4.0/), which permits use, distribution, and reproduction in any medium, provided the original work is properly cited 
From the beginning of the $21^{\text {st }}$ century, various construction activities, settlement and urban development of new territories continued in the Adjara seaside, accompanied by establishment, reconstruction and/or development of parks, gardens, and recreational places. For construction of residential buildings, shore protection works, other infrastructural and development projects, the construction materials are usually transported from one to another district of the city; the materials and goods are also imported from foreign countries. Most of ornamental plants (including their seeds and other planting material) are imported from abroad, which often results in unintentional introduction of alien weedy species, many of which are potential invaders. All of this adds to import of plants by the horticulturalists and plant lovers or the entrepreneurs for ornamental or production purposes; those plants spread in natural, disturbed, and artificial habitats, such as abandoned construction areas, roadsides, streams and canals, and so on.

The city of Batumi and its adjacent areas play an important role in the processes of immigration and spread of alien plants in the region. The city is an open gateway between the eastern and western countries. It is a trade and transportation hub between Europe and Asia, from where different goods are carried in and through Georgia. The famous Batumi Botanical Garden, established in the 1880 s and officially opened in 1912 , is the major horticultural and plant research center of the Caucasus; it also played and continues to play an exceptionally important role in both deliberate and unintentional plant introduction, acclimation and naturalization in the region.

Other areas contributing to the alien plants diversity in the Batumi area is the Batumi Boulevard stretching along the Black Sea shore; it is a green area with the centurylong history and rich introduced flora; together with other parks and green areas it also contributes to immigration and alien plants.

All those factors mentioned above promote intentional or unintentional spread of alien plants in the city territory and beyond. Many of those plants eventually find their way to the Batumi landfill territory with its peculiar transformed plant communities. In this area alien species often survive, proliferate, and form stable populations, in turn enriching the surrounding areas with unwanted aliens. Thus, our objective for the present research was to study the vegetation in the inactive, closed landfill area and its adjacent territory.

\section{Materials and methods}

The study site is located in the southwestern part of Georgia, in the floristic region of Adjara, 10-12 km from Batumi, on the right bank of the Chorokhi River, mainly at elevations of $1-5 \mathrm{~m}$ above sea level, between $41^{\circ} 36.022^{\prime} \mathrm{N}$ and $41^{\circ} 35.298^{\prime} \mathrm{E}$. The total area of the Batumi landfill is about 20 hectares, of which 10 hectares are occupied by the actively used area, while other areas are now closed for waste dumping; that results in ongoing processes of formation of stabilized plant communities (Fig. 1, 2).

The landfill has been operating since the last century (officially established in the study site in 1965). Initially, the waste was only from the territory of Batumi, but during recent years other municipalities of Adjara have been added as customers of the landfill services. Almost all types of waste are found in this area, including household, construction, industrial waste, etc.

The climate of the study area is characterized by specific features and spatial variability. Seaside Adjara in general has a humid subtropical climate. During most of the year, western humid winds are dominant and only in winter months inland winds occurrences increase. The average annual temperature is $+13^{\circ}-15^{\circ} \mathrm{C}$, while the coldest month's average temperature being +5.9 $7.5{ }^{\circ} \mathrm{C}$. Absolute temperatures rarely drop below $-8^{\circ}$. In the warmest months (July-August), the average temperature is $+22-23{ }^{\circ} \mathrm{C}$, the highest temperature reaching $+39-40{ }^{\circ} \mathrm{C}$. The average air humidity is $80-87 \%$ (Javakhishvili, 1926; Kordzakhia, 1961; Maruashvili, 1964; Nijaradze, 1978).

Investigation of the landfill flora was conducted during the period of 2015-2018. The main research method was the traditional route survey, which included plant description, photography, plant sampling, and laboratory processing, identification and herbarium preparation and curation. Laboratory activities were conducted in the Shota Rustaveli State University of Batumi, the Institute of Phytopathology and Biodiversity in Kobuleti.

Various floras and plant identification manuals and other scientific literature were used for identification of species: the identification manual of the Adjara flora (Dmitrieva, 1990a,); manuals of the Georgian flora (Field guide..., 1964, 1969; Fischer et al., 2018) and contributions on the alien flora of Adjara (Davitadze, 2001, 2002; Kikodze et al., 2010; Mikeladze, 2013, 2017; Sharabidze et al., 2018). Online resources and databases on invasive species worldwide were also used (Elpel, 2013; GBD, 2007-onward). The classification 


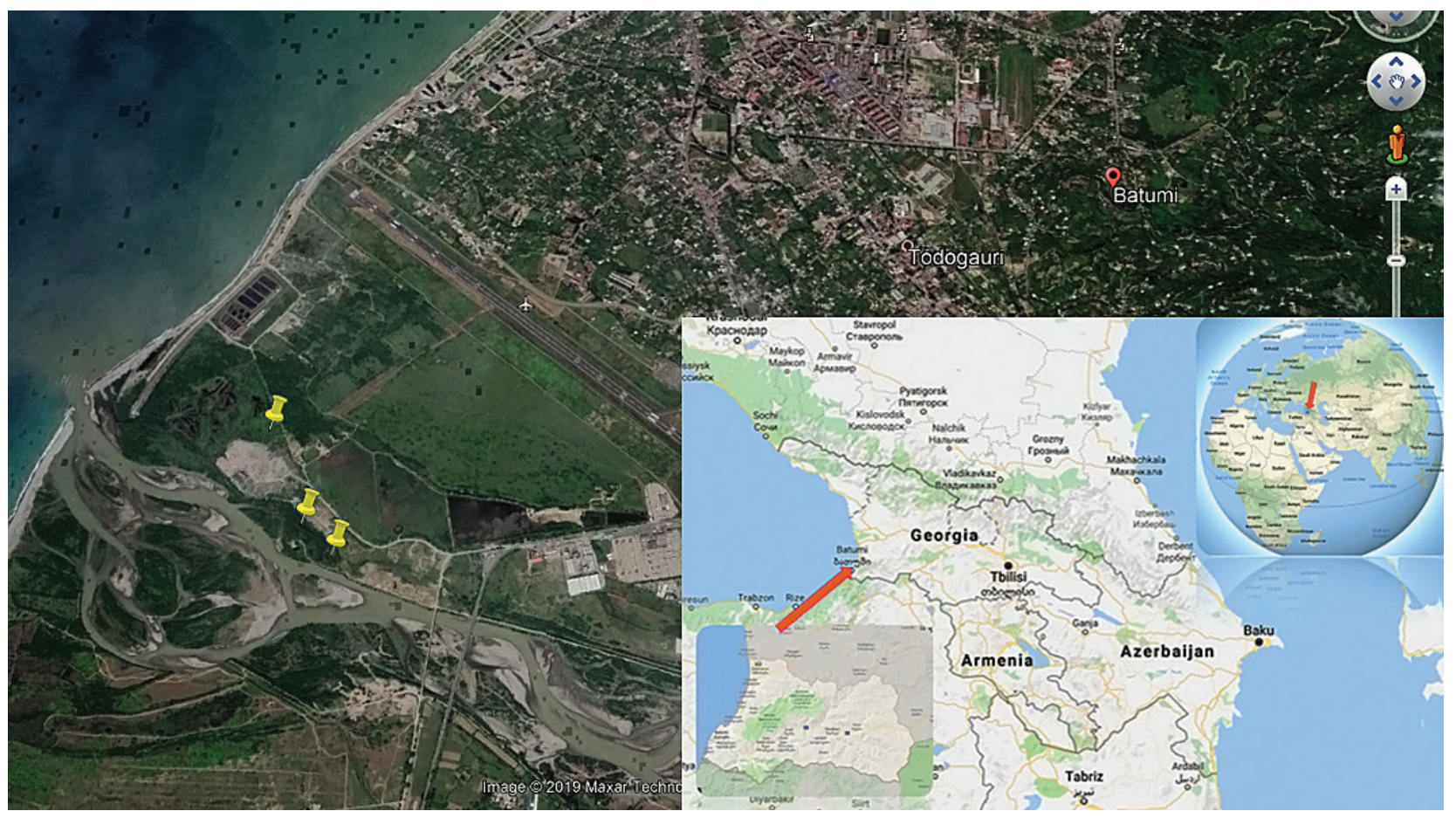

Fig. 1. Geographical position of the study site (investigated area)

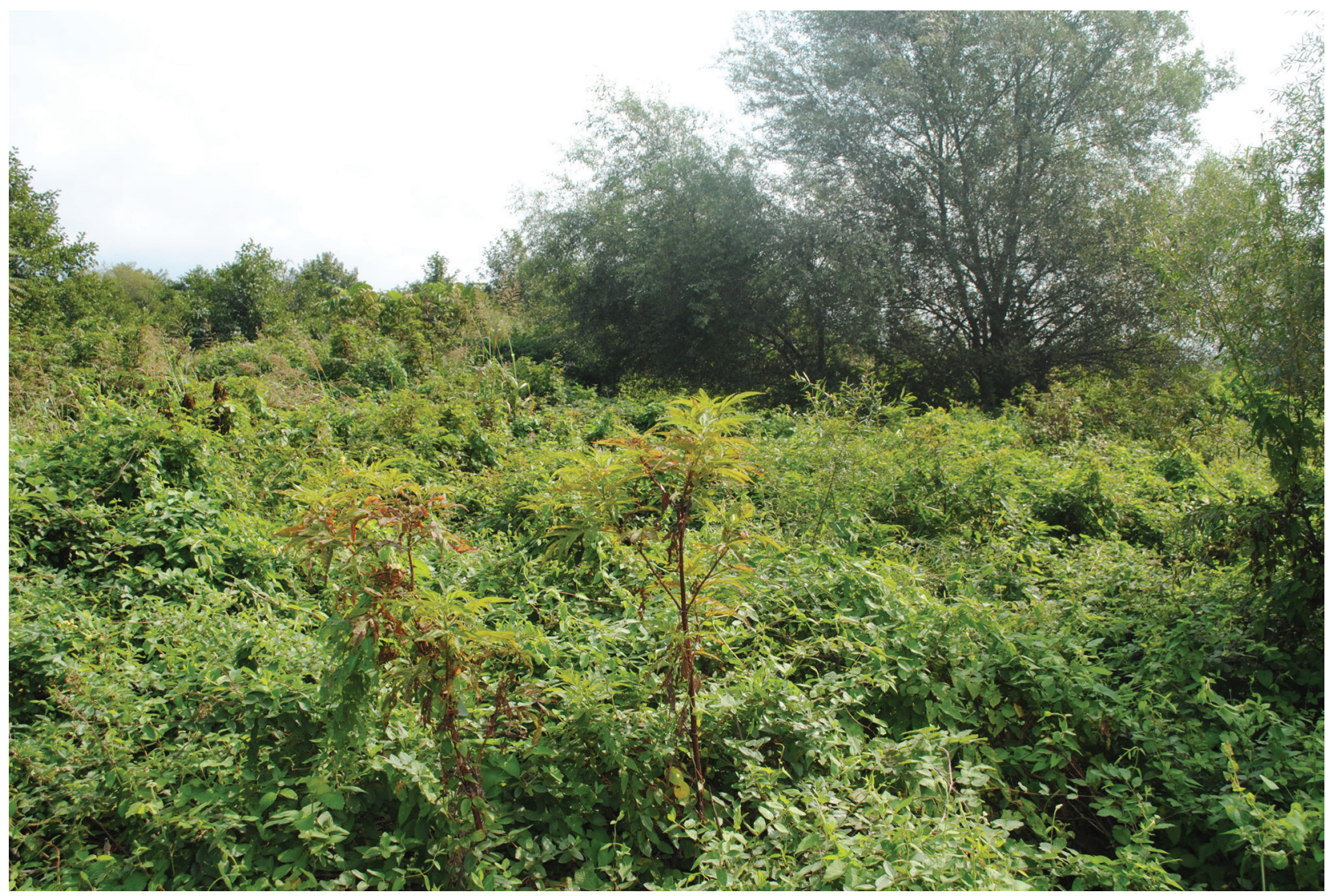

Fig. 2. Typical plant communities in the closed area of the Batumi landfill 
was checked according to the online databases of world plants (POWO, 2020-onward; WFO, 2020-onward). Life forms of plants were determined according to the Raunkiaer system (Raunkiaer, 1934). The origin of plant species is given following the flora of the Caucasus and other published and Internet resources (Takhtajan, 2003, 2006; etc.).

The time of the initial collection (first records) of nonnative plants in the Adjara floristic district was determined following the herbarium specimens deposited in the Batumi Botanical Garden (BATU) and from various publications (Davitadze, 2001, 2002; Kikodze et al., 2010; Mikeladze, 2013, 2017; Sharabidze et al., 2018).

\section{Results and discussion}

After identification of the plant samples collected in the Batumi landfill, we registered totally 244 species of vascular plants that represent 59 families and 163 genera (Table E1). Cryptogamic vascular plants are represented by three species of horsetails (Equisetum arvense L., E. palustre L., E. ramosissimum L.). Naturalized ferns and gymnosperms have not been observed during the study period. Among angiosperms, monocotyledons are represented by 43 species (17.62\%) belonging to eight families and 28 genera, while dicotyledonous plants contain 198 species $(81.14 \%)$ of 50 families and 134 genera.

Among the 59 families reported, 11 families are represented by five or more species each (totally $63.86 \%$, 156 species).These families are listed in Table 1.

The remaining 48 families are represented collectively by 88 species; these families are Convolvulaceae, Euphorbiaceae, Juncaceae, Malvaceae, Plantaginaceae, Rubiaceae - each with four species; Apiaceae, Commelinaceae, Equisetaceae, Onagraceae, Plantaginaceae, Scrophulariaceae, Typhaceae each with three species; Adoxaceae, Araliaceae, Boraginaceae, Gentianaceae, Juglandaceae, Moraceae, Ranunculaceae, Salicaceae, Simaroubaceae, Violaceae, Verbenaceae - each with two species. The families Araceae, Balsaminaceae, Betulaceae, Caprifoliaceae, Cleomaceae, Cornaceae, Elaeagnaceae, Gentianaceae, Geraniaceae, Hypericaceae, Iridaceae, Lythraceae, Nyctaginaceae, Orobanchaceae, Papaveraceae, Phytolaccaceae, Platanaceae, Portulacaceae, Primulaceae, Sapindaceae, Saxifragaceae, Smilacaceae, Urticaceae, Vitaceae are represented each by one species.

Украӥнський ботанічний журнал, 2020, 77(6)
Table 1. Families represented in the area by more than five species each

\begin{tabular}{|l|l|c|c|}
\hline No & \multicolumn{1}{|c|}{ Families } & Number of species & Species, $\%$ \\
\hline 1 & Asteraceae/Compositae & 43 & 17.62 \\
\hline 2 & Poaceae/Gramineae & 22 & 9.01 \\
\hline 3 & Fabaceae/Leguminosae & 18 & 7.37 \\
\hline 4 & Lamiaceae/Labiatae & 13 & 5.32 \\
\hline 5 & Polygonaceae & 12 & 4.91 \\
\hline 6 & Rosaceae & 10 & 4.09 \\
\hline 7 & Cyperaceae & 10 & 4.09 \\
\hline 8 & Amaranthaceae & 9 & 3.68 \\
\hline 9 & Solanaceae & 7 & 2.86 \\
\hline 10 & Brassicaceae & 7 & 2.86 \\
\hline 11 & Caryophyllaceae & 5 & 2.05 \\
\hline \multicolumn{2}{|l|}{ Total in 11 families } & 156 species & 63.86 \\
\hline
\end{tabular}

The best represented genera by their species number are: Persicaria Mill. (7 species); Amaranthus L., Solanum L., Trifolium L. (each with 5 species); Artemisia L., Carex L., Rubus L. (each with 4 species); Cyperus L., Equisetum L., Erigeron L., Euphorbia L., Galium L., Juncus L., Mentha L., Poa L., Rumex L., Senecio L., Stellaria L., Veronica L., Xanthium L. (each with 3 species).

Of the species registered in the Batumi landfill, 86 species $(35.25 \%)$ are considered native and 158 species $(64.75 \%)$ are aliens (introduced). Among aliens, 48 species are of East Asian origin, 34 species originated in Europe, 1 species is Australian, 13 - South American, 29 - North American, and 33 are Mediterranean ones (Fig. 3).

Our phytogeographical analysis demonstrated the largest number of East Asian species, which is due to many factors. In particular, those factors include similar climatic conditions (including high humidity, precipitation, favorable temperatures during the whole year, fertile soils, etc.). Also, it reflects the history of introduction of taxa for cultivation, as well as their associated weeds. For example, it is known that East Asia was considered among highest geographical priorities for introduction of plants in the Batumi Botanical Garden since its establishment. The species of the Mediterranean and European origin follow by their number, which is also partly determined by the phytogeographic structure of the Adjara flora.

The analysis of life forms of the Batumi landfill flora demonstrated the predominance of therophytes and hemicryptophytes. Therophytes (herbaceous annuals) are represented by $108(44.26 \%)$ species. The second 

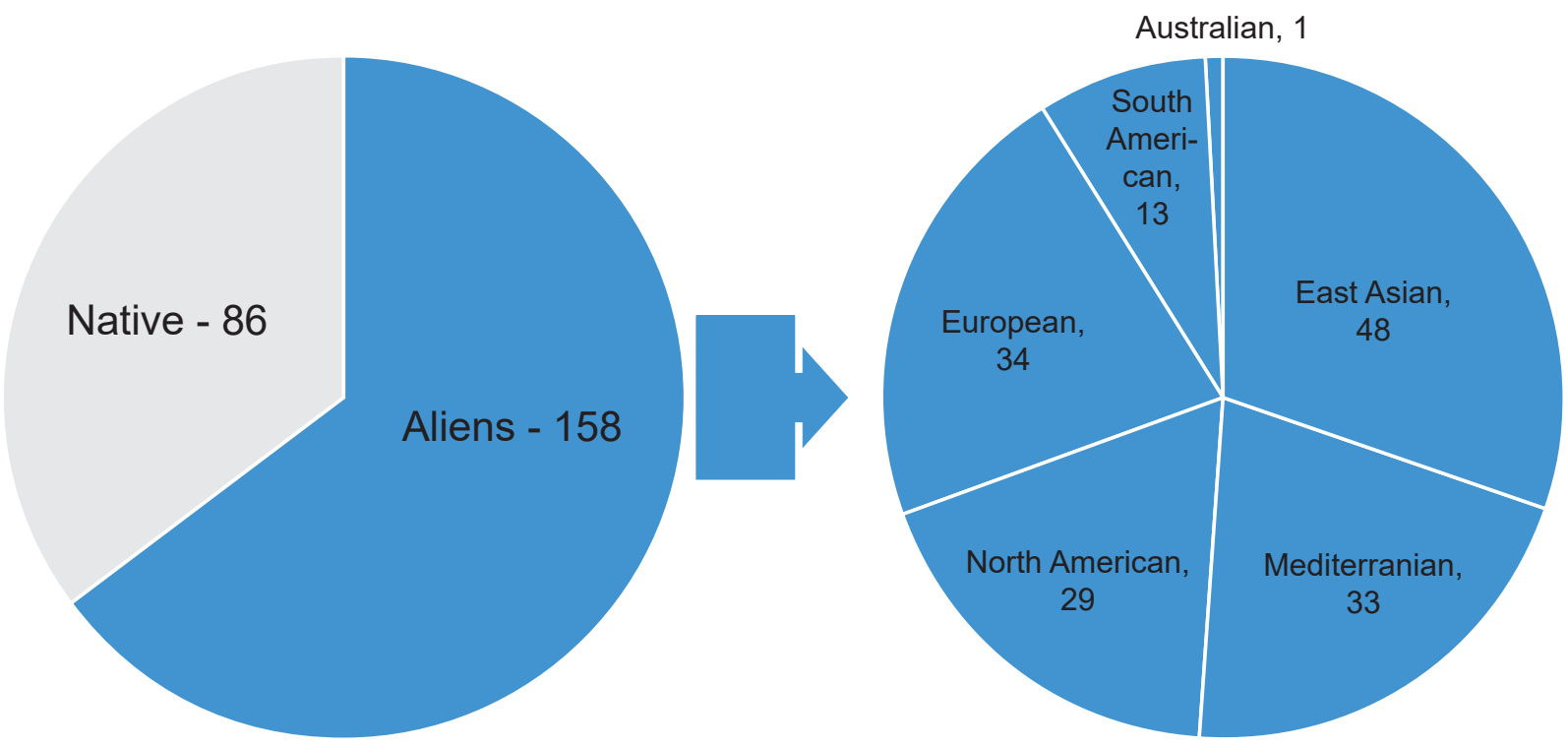

Fig. 3. Groups of Batumi landfill plants by their origin

place is occupied by hemicryptophytes with 60 species $(26.10 \%)$ of mainly biennial and perennial herbaceous plants (Table 2).

The dominant positions of therophytes and hemicryptophytes are related to the peculiarities of the species composition of the local ruderal flora. Phanerophytes are quite diverse, out of 33 species 14 are local and 19 are of alien origin.

In the study area, phanerophytes usually flower, bear fruit, establish seedlings normally, and thus they are characterized by a complete cycle of development; sometimes they dominate in local plant communities.

Besides the typical ruderal species recorded in the Batumi landfill (inactive or closed area) we came across the species characteristic for various habitats, such as forests, moist meadows, low and high mountain zones, etc. Out of 244 species, 94 are representatives of the ruderal flora (Tabl. E1).

Furthermore, a number of sub-spontaneously distributed cultivated species (occasional escapes, such as maize, beans, tomato, pumpkin, watermelon, melon and other crop plants) were also found. Usually such garden escapes or agricultural crops are only of ephemeral occurrence, not forming stable populations.

\section{Conclusions}

Among 244 species of 163 genera and 59 families registered to date in the Batumi landfill area, we have
Table 2. Life forms of plants in the Batumi landfill flora

\begin{tabular}{|l|l|c|c|}
\hline No & \multicolumn{1}{|c|}{ Life Form } & Number of species & Species, \% \\
\hline 1 & Therophytes & 108 & 44.26 \\
\hline 2 & Hemicryptophytes & 63 & 26.10 \\
\hline 3 & Phanerophytes & 33 & 13.52 \\
\hline 4 & Cryptophytes & 25 & 10.49 \\
\hline 5 & Chamaephytes & 13 & 5.35 \\
\hline \multicolumn{2}{|l|}{ Total } & 244 & 100 \\
\hline
\end{tabular}

met species which are characteristic for different habitat of the region of Adjara. 94 species of plants $(38.52 \%$ of the total species list) are species characteristic for ruderal habitats.

Cryptogamic plants are represented by 3 species of horsetails. Dicotyledonous plants are represented by 198 species and monocotyledons - by 43 species. Families represented by more than 10 species each are Asteraceae/ Compositae, Poaceae/Gramineae, Fabaceael Leguminosae, Lamiaceae/Labiatae, Polygonaceae, and Rosaceae.

The analysis of plants life forms registered in the on Batumi landfill demonstrated that therophytes form the dominant group (44.26\%), followed by hemicryptophytes (63 species or $26.10 \%$ ). The dominant positions of therophytes and hemicryptophytes are in accordance with their position in other ruderal floras.

Among the species, 86 are considered native and 158 are aliens. Among aliens, the largest group (in terms of the number of species) is comprised by plants of East Asian origin (48 species). That is due to similar climatic 
conditions of Adjara and many East Asian regions (including high humidity and precipitation, favorable temperatures during the whole year, fertile soils, etc.).

We understand that the list of species reliably registered to date in the Batumi landfill area is not complete and additional species (both alien and native ones) will be registered there in the future. Because of that we are planning to continue our surveys of the landfill flora, especially for monitoring invasive and potentially invasive species. The species list presented here will serve as a reference checklist reflecting the present state of our knowledge of the local flora; it will be amended and improved during the future research.

\section{References}

Davitadze M. 2001. Adventive flora of Adjara. Batumi: Batumi

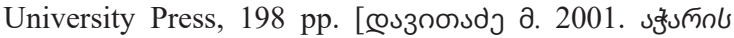

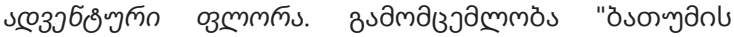

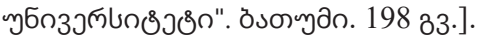

Davitadze M. 2002. Biomorphological analysis to the flora of Adjara. Batumi: Batumi University Press, 215 pp.

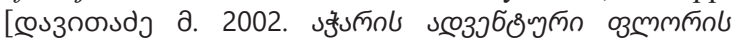

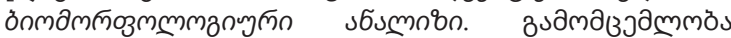

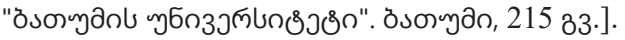

Dmitrieva A.A. 1990a. Opredelitel rastenyi Adzharyi, vol. 1. Tbilisi: Metsniereba, 325 pp. [Дмитриева А.А. 1990. Определитель растений Аджарии, т. 1. Тбилиси: Мецниереба, 325 с.].

Dmitrieva A.A. 1990b. Opredelitel rastenyi Adzharyi, vol. 2. Tbilisi: Metsniereba, 278 pp. [Дмитриева А.А. 1990. Определитель растений Аджарии, т. 2. Тбилиси: Мецниереба, 278 с.].

Field guide to the flora of Georgia, vol. 1. 1964. Tbilisi:

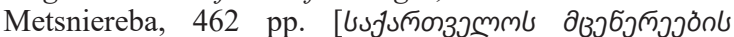

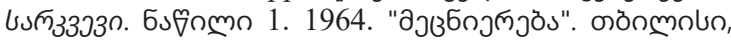
462 33.]

Field guide to the flora of Georgia, vol. 2. 1969. Tbilisi:

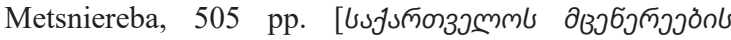

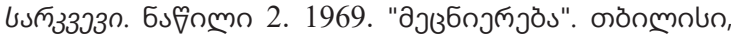
505 33.]

Fischer E., Groger A., Lobin W. 2018. Illustrated Field Guide to the flora of Georgia (South Caucasus). In: Koblenz Geographical Colloquia, Series Biogeographical Monographs, vol. 3. Koblenz: Universität KoblenzLandau, $830 \mathrm{pp}$.

GBD. Georgian Biodiversity Database. 2007-onward. Available at: http://www.biodiversity-georgia.net (Accessed 25 November 2019).

Javakhishvili A. 1926. Geography of Georgia, vol. 1. Tbilisi:

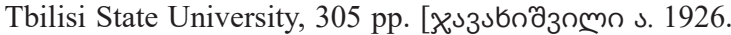

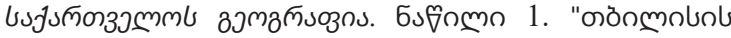

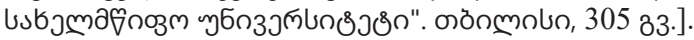

Kikodze D., Memiadze N., Kharazishvili D., Manvelidze Z., Mueller-Shaerer H. 2010. The alien flora of Georgia. $2^{\text {nd }}$ ed. Joint SNSF SCOPES and FOEN publication, $36 \mathrm{pp}$.

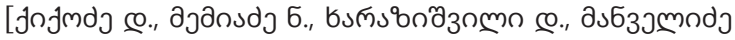

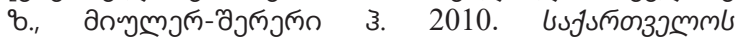

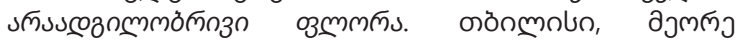
зงวмъววง. 36 з3.].

Kordzakhia M. 1961. The climate of Georgia. Tbilisi: Georgian Academy of Sciences, 249 pp. [зmmdstons

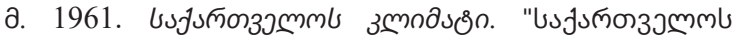

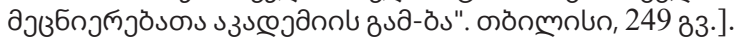

Maruashvili L. 1964. Physical geography of Georgia. Tbilisi:

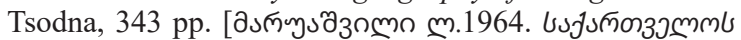

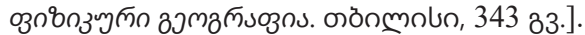

Mikeladze I., Davitadze M., Bolkvadze G., Metreveli M., Chagalidze R. 2013. In: The role of botanical garden in conservation of plant diversity, part 2. Batumi,

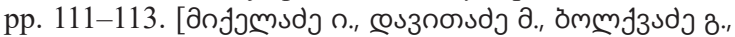

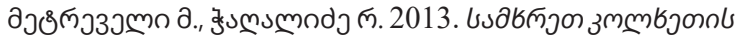

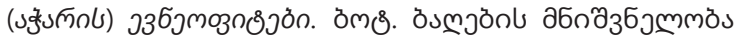

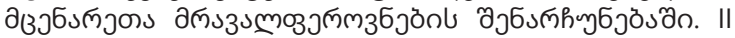
ธงซึกmก. ösoyan. 111-113].

Mikeladze I., Bolkvadze G., Metreveli M., Chagalidze R., Davitadze M., Sharabidze A. 2017. Brasilian Vervain (Verbena brasiliensis) in Colkheti flora. Annals of Agrarian Science, 15(2): 198-200. https://doi.org/10.1016/j. aasci.2017.05.013

Nijaradze N., Djibuti N. 1978. Adjara. Batumi: Soviet Adjara

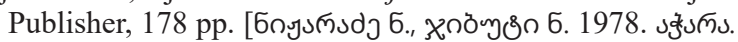
178 33.].

POWO. Plants of the World Online. 2020-onward. Facilitated by the Royal Botanic Gardens, Kew. Available at: http:// www.plantsoftheworldonline.org (Accessed 18 July 2020).

Raunkiær Ch. 1934. The life-forms of plants and their bearing on geography. In: The Life Forms of Plants and Statistical Plant Geography, being the collected papers of C. Raunkiaer [transl. from Danish]. Oxford: Clarendon Press, pp. 2-104.

Sharabidze A., Mikeladze I., Gvarishvili N., Davitadze M. 2018. Invasion of foreign origin (Alien) woody plants in Seaside Adjara. Biological Forum - An International Journal 10(2): 109-113.

Takhtajan A.L. (ed.). 2003. Caucasian Flora Conspectus, vol. 1. St.Petersburg: St.Petersburg University Press, 204 pp. [Тахтаджян А.Л. (ред.). 2003. Конспект флоры Кавказа, т. 1. Санкт-Петербург: Изд-во Санкт-Петербургского университета, 204 с.].

Takhtajan A.L. (ed.). 2006. Caucasian Flora Conspectus, vol. 2. St.Petersburg: St.Petersburg University Press, 467 pp. [Тахтаджян А.Л. (ред.). 2006. Конспект флоры Кавказа, т. 2. Санкт-Петербург: Изд-во Санкт-Петербургского университета, 467 с.].

Elpel T.J. 2013. Botany in a day. The patterns method of plant identification. Pony: HOPS Press, LLC, 235 pp.

WFO. World Flora Online. 2020-onward. Available at: http:// www.worldfloraonline.org (Accessed 25 November 2020).

Recommended for publication by M.V. Shevera 
Electronic Supplement to: Mikeladze \& Sharabidze 2020. The flora of the Batumi landfill (Adjara, Georgia).

Ukrainian Botanical Journal, 77(6)

Table E1. A checklist of the Batumi landfill flora

Life form: $\mathrm{Ph}$ - Phanerophyte, Th - Therophyte, $\mathrm{He}$ - Hemicryptophyte, $\mathrm{Cr}$ - Cryptophyte, $\mathrm{Ch}$ - Chamaephyte; $\underline{\text { Class: }}$ Eu - Eudicots, Mo - Monocots, S - spore-bearing plants; Ecological group: R - ruderal, $\mathrm{F}$ - forest plant, $\mathrm{P}$ - lowland and pioneer plant, $\mathrm{G}$ grassland, scrub and rock plant, $\mathrm{H}$ - marsh and wet meadow plant, $\mathrm{M}$ - mountain plant); First recorded time in the Adjara floristic region (FRT): AnT - ancient times, XX beg. - beginning of the twentieth century

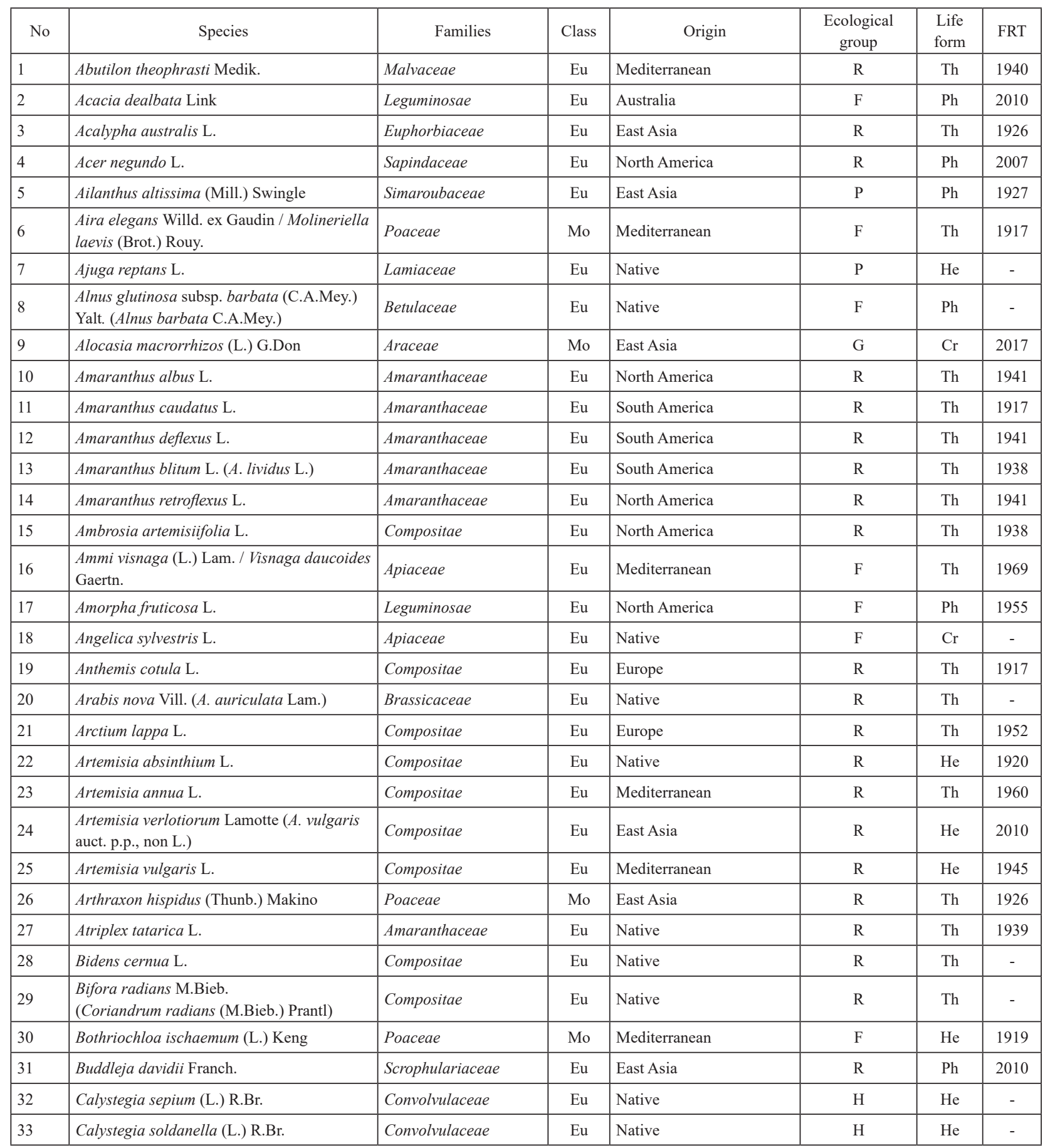




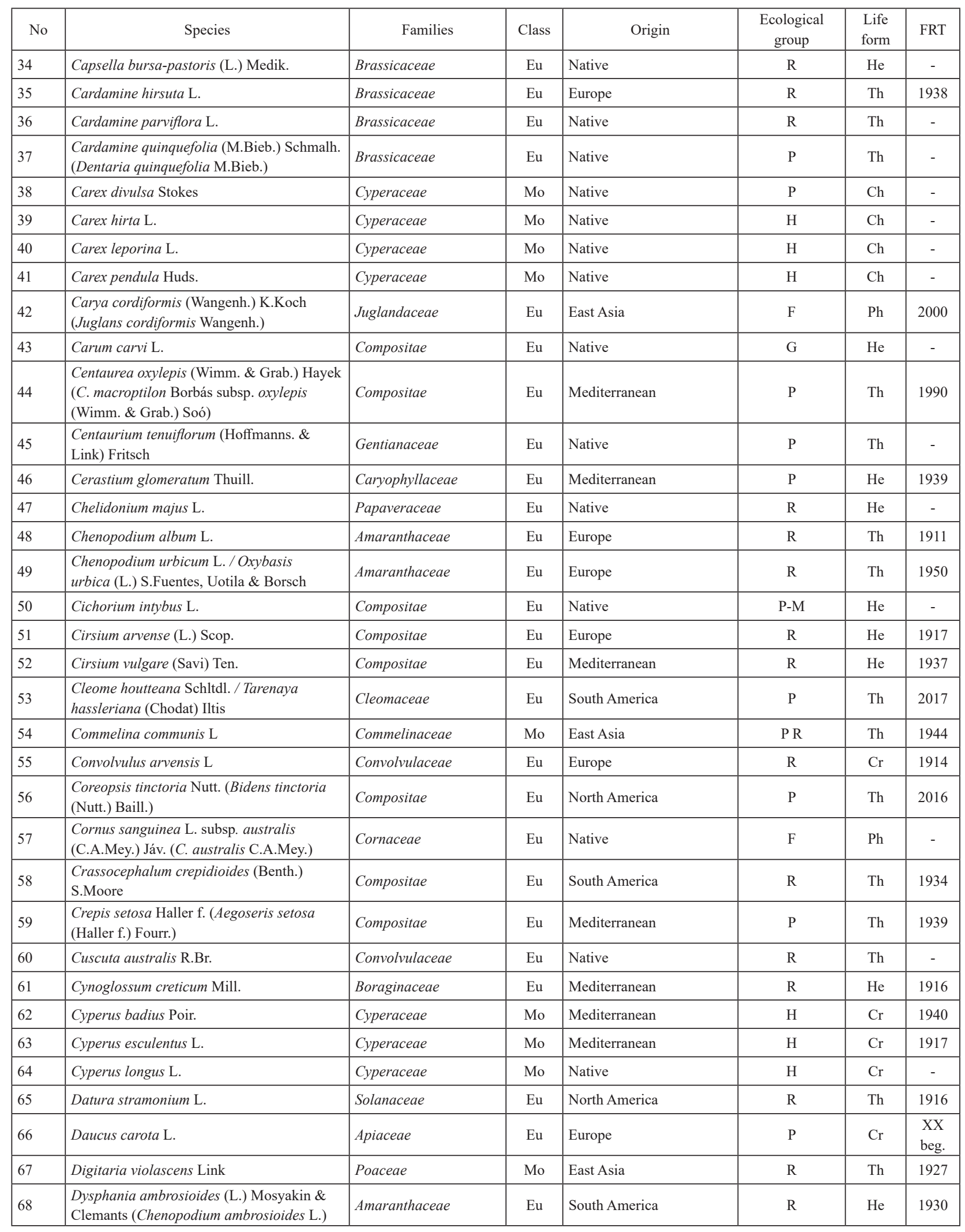




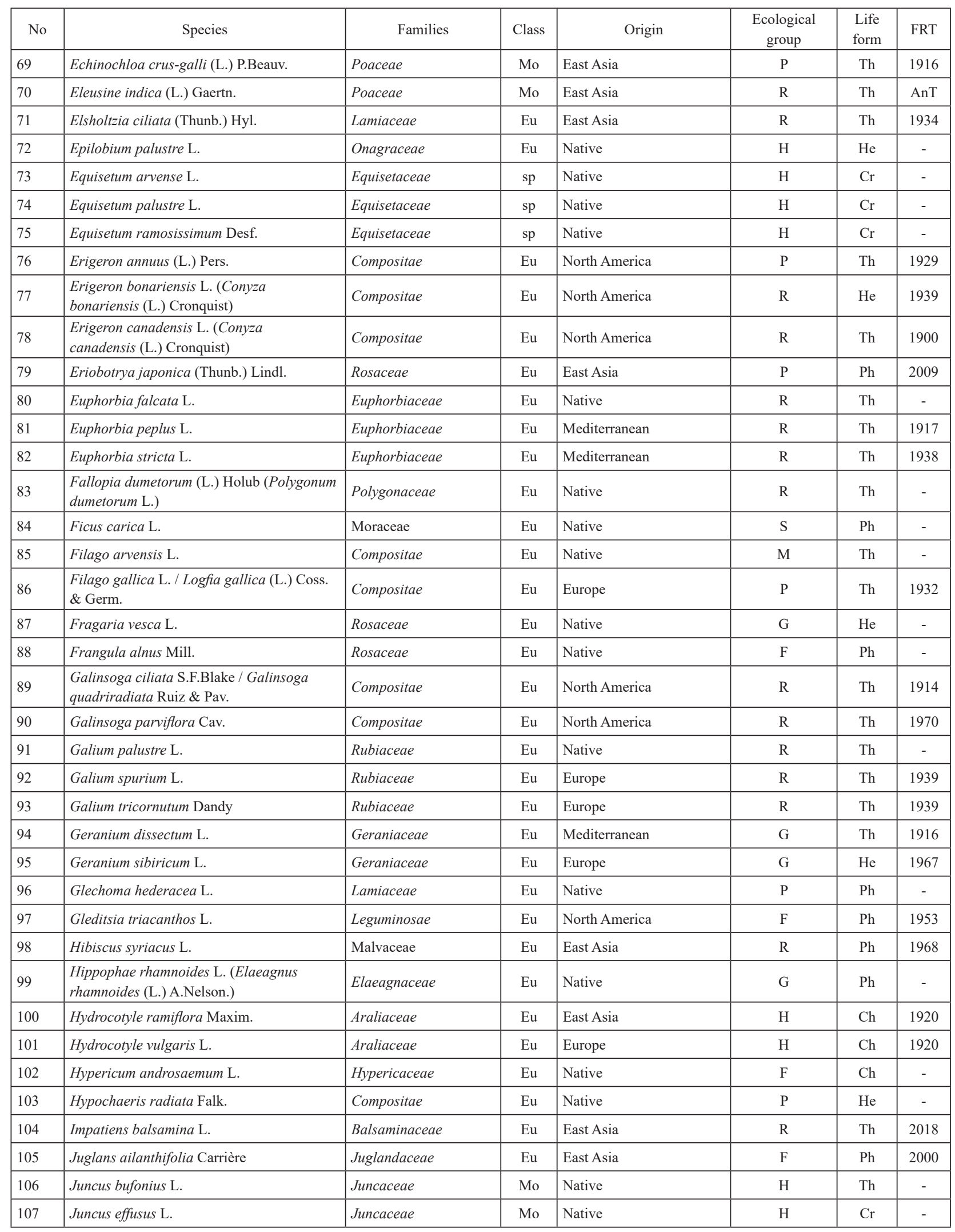




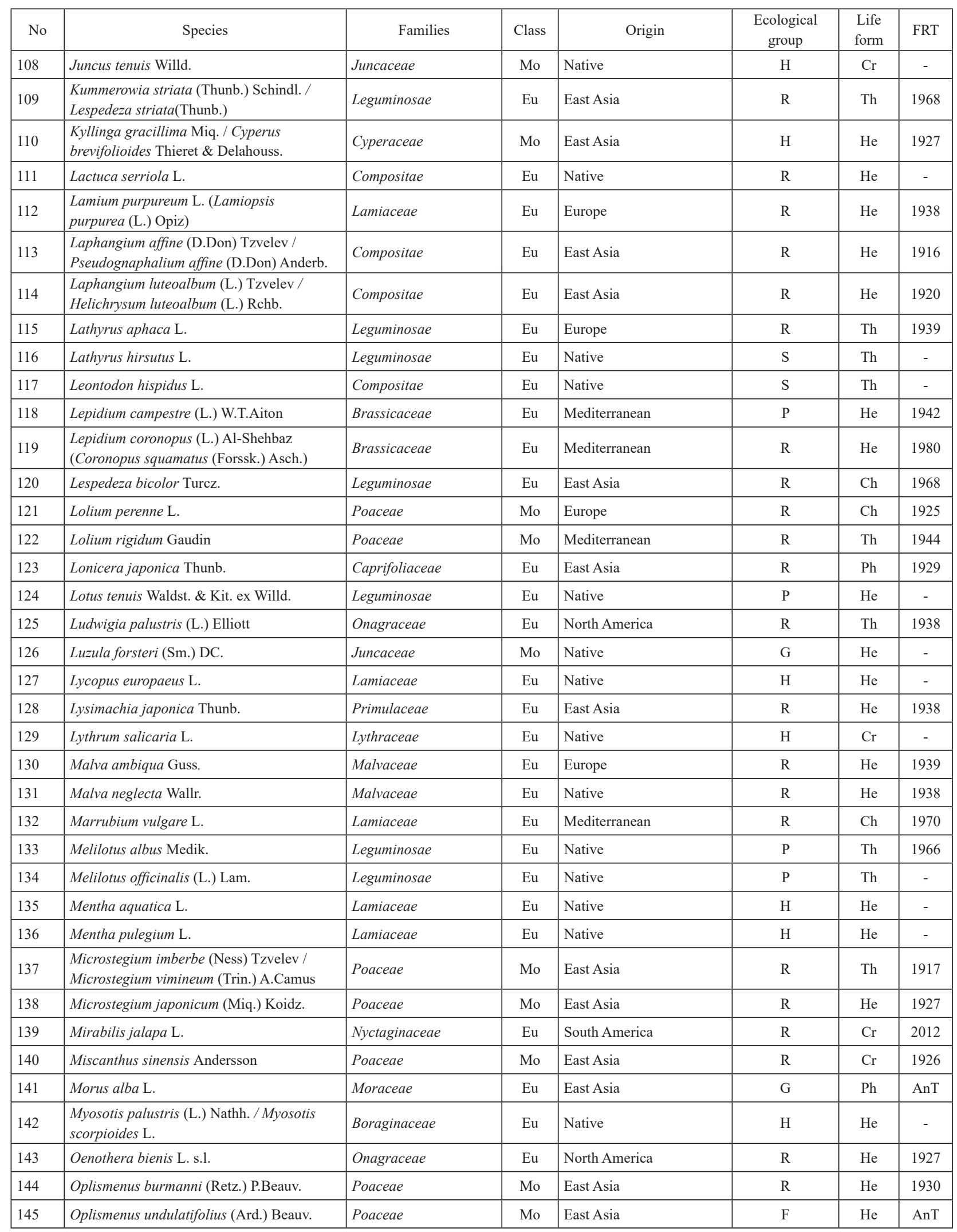




\begin{tabular}{|c|c|c|c|c|c|c|c|}
\hline No & Species & Families & Class & Origin & $\begin{array}{l}\text { Ecological } \\
\text { group }\end{array}$ & $\begin{array}{l}\text { Life } \\
\text { form }\end{array}$ & FRT \\
\hline 146 & Oxalis corniculata $\mathrm{L}$. & Lamiaceae & $\mathrm{Eu}$ & North America & $\mathrm{R}$ & Th & 1916 \\
\hline 148 & Parentucellia latifolia Caruel. & Orobanchaceae & $\mathrm{Eu}$ & Europe & $\mathrm{P}$ & Th & 2009 \\
\hline 149 & Parthenocissus quinquefolia (L.) Planch. & Vitaceae & $\mathrm{Eu}$ & North America & $\mathrm{R}$ & $\mathrm{Ph}$ & 2015 \\
\hline 151 & Paspalum thunbergii Kunth ex Steud. & Poaceae & Mo & East Asia & $\mathrm{R}$ & $\mathrm{Cr}$ & 1920 \\
\hline 152 & $\begin{array}{l}\text { Perilla nankinensis (Lour.) Decne / Perilla } \\
\text { frutescens var. crispa (Thunb.) H.Deane }\end{array}$ & Lamiaceae & $\mathrm{Eu}$ & East Asia & $\mathrm{R}$ & Th & 1910 \\
\hline 153 & $\begin{array}{l}\text { Persicaria hydropiper }(\mathrm{L} .) \text { Delarbre } \\
\text { (Polygonum hydropiper L.) }\end{array}$ & Polygonaceae & $\mathrm{Eu}$ & Native & $\mathrm{H}$ & Th & - \\
\hline 156 & $\begin{array}{l}\text { Persicaria orientalis (L.) Spach. (Polygonum } \\
\text { orientale L.) }\end{array}$ & Polygonaceae & $\mathrm{Eu}$ & East Asia & $\mathrm{R}$ & Th & 1924 \\
\hline 157 & $\begin{array}{l}\text { Persicaria perfoliata }(\mathrm{L} .) \text { H.Gross } \\
\text { (Polygonum perfoliatum L.) }\end{array}$ & Polygonaceae & $\mathrm{Eu}$ & East Asia & $\mathrm{R}$ & Th & 1924 \\
\hline 158 & $\begin{array}{l}\text { Persicaria posumbu (Buch.-Ham. ex D.Don) } \\
\text { H.Gross (Polygonum posumbu Buch.-Ham. } \\
\text { ex D.Don) }\end{array}$ & Polygonaceae & $\mathrm{Eu}$ & East Asia & $\mathrm{R}$ & Th & 1910 \\
\hline 159 & $\begin{array}{l}\text { Persicaria thunbergii (Siebold \& Zucc.) } \\
\text { H.Gross (Polygonum thunbergii Siebold \& } \\
\text { Zucc.) }\end{array}$ & Polygonaceae & $\mathrm{Eu}$ & East Asia & $\mathrm{H}$ & Th & 1927 \\
\hline 160 & Physalis ixocarpa Brot. ex Hornem. & Solanaceae & $\mathrm{Eu}$ & North America & $\mathrm{P}$ & Th & 1935 \\
\hline 166 & Poa pratensis $\mathrm{L}$. & Poaceae & Mo & Native & $\mathrm{G}$ & $\mathrm{He}$ & - \\
\hline 167 & Polycarpon tetraphyllum (L.) L. & Caryophyllaceae & $\mathrm{Eu}$ & Mediterranean & $\mathrm{P}$ & Th & 1939 \\
\hline 168 & Polygonum aviculare L. & Polygonaceae & $\mathrm{Eu}$ & Europe & $\mathrm{R}$ & $\mathrm{Th}$ & 1917 \\
\hline 169 & $\begin{array}{l}\text { Potentilla indica (Andrews) Th.Wolf. } \\
\text { (Duchesnea indica (Andrews) Teschem.) }\end{array}$ & Rosaceae & $\mathrm{Eu}$ & East Asia & $\mathrm{P}$ & $\mathrm{He}$ & 1924 \\
\hline 170 & Portulaca oleracea L. s.1. & Portulacaceae & $\mathrm{Eu}$ & Mediterranean & $\mathrm{R}$ & Th & 1977 \\
\hline 171 & Prunella vulgaris $\mathrm{L}$. & Lamiaceae & $\mathrm{Eu}$ & Native & $\mathrm{F}$ & $\mathrm{Th}$ & - \\
\hline 172 & Pycreus flavescens (L.) P.Beauv. ex Rchb. & Cyperaceae & Mo & Native & $\mathrm{H}$ & Th & - \\
\hline 173 & Ranunculus muricatus $\mathrm{L}$. & Ranunculaceae & $\mathrm{Eu}$ & Mediterranean & $\mathrm{R}$ & Th & 1917 \\
\hline 174 & Ranunculus sceleratus L. & Ranunculaceae & $\mathrm{Eu}$ & Europe & $\mathrm{H}$ & $\mathrm{He}$ & 1939 \\
\hline 175 & Rhus javanica $\mathrm{L}$. & Simaroubaceae & $\mathrm{Eu}$ & East Asia & $\mathrm{R}$ & $\mathrm{Ph}$ & 1929 \\
\hline 176 & Robinia pseudoacacia $\mathrm{L}$. & Leguminosae & $\mathrm{Eu}$ & North America & $\mathrm{F}$ & $\mathrm{Ph}$ & 1965 \\
\hline 177 & Rosa multiflora Thunb. & Rosaceae & $\mathrm{Eu}$ & East Asia & $\mathrm{P}$ & $\mathrm{Ph}$ & 2016 \\
\hline 178 & Rubus anatolicus Focke. & Rosaceae & $\mathrm{Eu}$ & Native & $\mathrm{F}$ & $\mathrm{Ph}$ & - \\
\hline 179 & Rubus caesius $\mathrm{L}$. & Rosaceae & $\mathrm{Eu}$ & Native & $\mathrm{F}$ & $\mathrm{Ph}$ & - \\
\hline 180 & Rubus proiectus A.Beek (Rubus hirtus auct.) & Rosaceae & $\mathrm{Eu}$ & Native & $\mathrm{F}$ & $\mathrm{Ph}$ & - \\
\hline
\end{tabular}




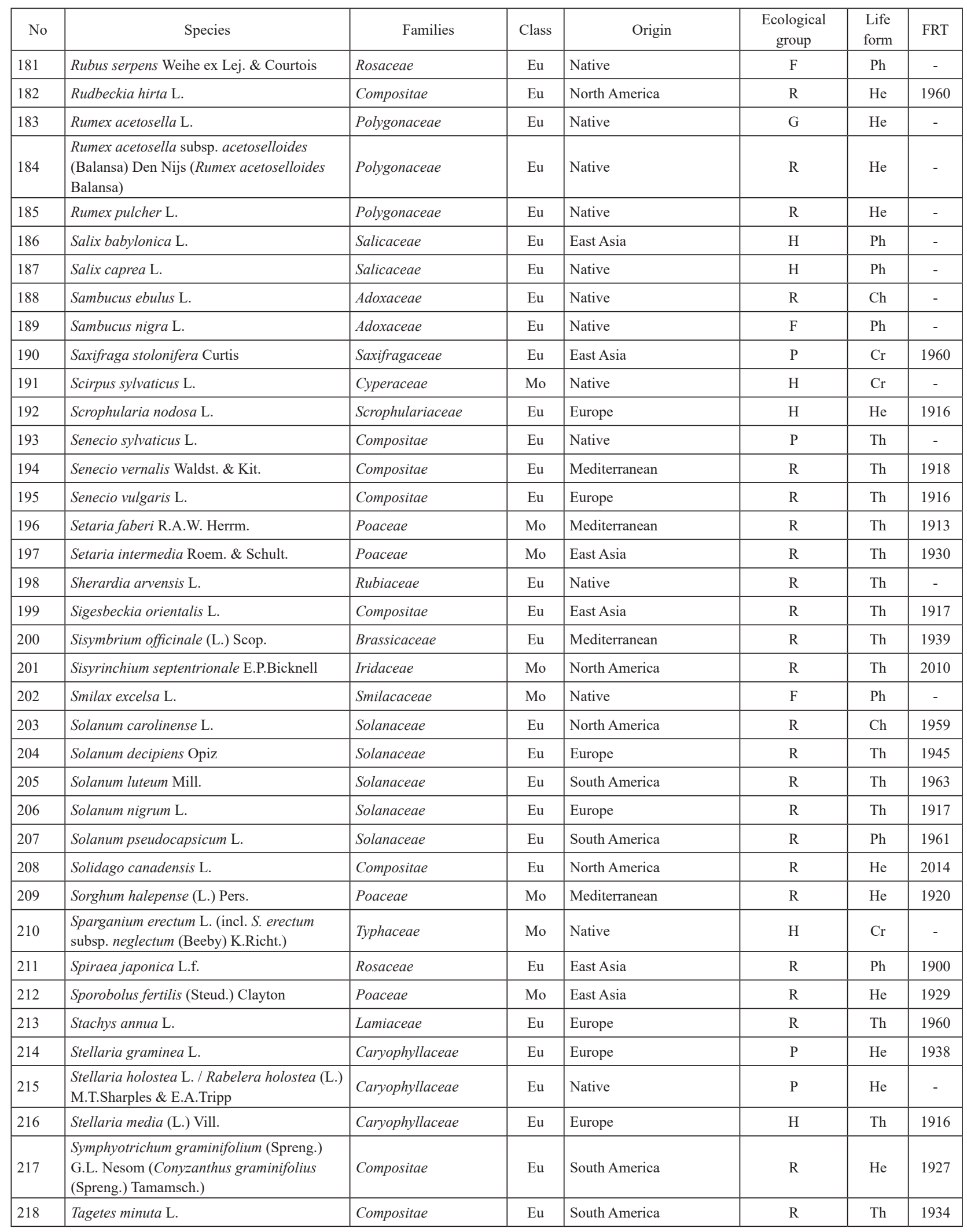




\begin{tabular}{|c|c|c|c|c|c|c|c|}
\hline No & Species & Families & Class & Origin & $\begin{array}{l}\text { Ecological } \\
\text { group }\end{array}$ & $\begin{array}{l}\text { Life } \\
\text { form }\end{array}$ & FRT \\
\hline 219 & Taraxacum officinale Wigg. & Compositae & $\mathrm{Eu}$ & Native & G & $\mathrm{Cr}$ & - \\
\hline 221 & Torilis japonica (Houtt.) DC. & Compositae & Eu & East Asia & $\mathrm{R}$ & $\mathrm{He}$ & 1916 \\
\hline 222 & Tradescantia fluminensis Vell. & Commelinaceae & Mo & South America & $\mathrm{R}$ & $\mathrm{He}$ & 1960 \\
\hline 224 & Trifolium campestre Schreb. & Leguminosae & $\mathrm{Eu}$ & Native & $\mathrm{P}$ & Th & - \\
\hline 225 & Trifolium diffusum Ehrh. & Leguminosae & $\mathrm{Eu}$ & Mediterranean & $\mathrm{P}$ & Th & 1948 \\
\hline 226 & Trifolium echinatum M.Bieb. & Leguminosae & $\mathrm{Eu}$ & Mediterranean & $\mathrm{P}$ & Th & 1939 \\
\hline 227 & Trifolium fragiferum $\mathrm{L}$. & Leguminosae & $\mathrm{Eu}$ & Native & $\mathrm{P}$ & Th & - \\
\hline 231 & Urtica dioica $\mathrm{L}$. & Urticaceae & $\mathrm{Eu}$ & Atlantic Europe & $\mathrm{R}$ & $\mathrm{He}$ & AnT \\
\hline 232 & Verbascum blattaria L. & Scrophulariaceae & $\mathrm{Eu}$ & Native & $\mathrm{R}$ & $\mathrm{Ch}$ & - \\
\hline 233 & Verbena brasiliensis Vell. & Verbenaceae & $\mathrm{Eu}$ & South America & $\mathrm{P}$ & $\mathrm{Ch}$ & 2015 \\
\hline 234 & Verbena officinalis $\mathrm{L}$. & Verbenaceae & $\mathrm{Eu}$ & Europe & $\mathrm{R}$ & $\mathrm{Ch}$ & $\begin{array}{l}\mathrm{XX} \\
\text { beg. }\end{array}$ \\
\hline 235 & Veronica anagallis-aquatica $\mathrm{L}$. & Plantaginaceae & $\mathrm{Eu}$ & Native & $\mathrm{R}$ & $\mathrm{He}$ & - \\
\hline 236 & Veronica persica Poir. & Plantaginaceae & $\mathrm{Eu}$ & Mediterranean & $\mathrm{R}$ & Th & 1914 \\
\hline 237 & Veronica serpyllifolia L. & Plantaginaceae & $\mathrm{Eu}$ & Native & $\mathrm{R}$ & $\mathrm{He}$ & - \\
\hline 238 & Vicia lathyroides $\mathrm{L}$. & Leguminosae & $\mathrm{Eu}$ & Mediterranean & $\mathrm{R}$ & Th & 1939 \\
\hline 244 & Xanthium strumarium L. & Compositae & $\mathrm{Eu}$ & North America & $\mathrm{R}$ & Th & $\begin{array}{l}\mathrm{XX} \\
\text { beg. }\end{array}$ \\
\hline
\end{tabular}

